\title{
The Description and Documentation of the Karonese Semantic
}

\author{
Rosita Ginting $^{1}$, Leman Sembiring ${ }^{2}$, Joy Sembiring ${ }^{3}$, Sugihana Sembiring ${ }^{4}$ \\ ${ }^{1234}$ Faculty of Cultural Sciences, University of Sumatera Utara, Medan-Indonesia \\ Jl. Universitas No.19, Padang Bulan, Medan Baru, Kota Medan, Sumatera Utara \\ ,gintingzrosita@gmail.com, sembiringsugihana19@gmail.com
}

\begin{abstract}
The research, recording, and documentation of Karonese Semantic is an attempt to reidentify the types of word meaning, meaning relation, meaning change and meaning of names in Karonese. The semantics of Karo language is a type of communication that reflects the cultural values of the region, and is a part of the national culture. The Karonese sematic needs to be done in an attempt to recapture as clear information as possible about the types, relationships and changes in the meaning and meaning of names in Karonese. Semantics, which is a science of meanings of words, helps to answer it. To get research data in the form of descriptive qualitative, we applied an observation method with the technique of involment and communication, a method of interview with the recording and noting down technique, and a method of documentation with noting down technique. The results are presented in narrative form theory with structural analysis.
\end{abstract}

Keywords: Karonese Semantic, Communication, Structural Analysis

\begin{abstract}
Abstrak
Penelitian, pencatatan, dan pendokumentasian semantik Bahasa Karo adalah suatu upaya untuk mengidentifikasi kembali jenis-jenis makna kata, relasi maknakata, perubahan makna dan makna nama-nama dalam Bahasa Karo. Semantik Bahasa Karo adalah jenis komunikasi yang mencerminkan nilai-nilai budaya daerah, dan merupakan bagian dari kebudayaan nasional. Karena itu penelitian semantik Karo perlu dilakukan dalam usaha menjaring kembali informasi yang sejelas-jelasnya mengenai jenis, relasi dan perubahan makna serta makna nama-nama dalam Bahasa Karo, Semantik yang merupakan suatu ilmu membantu untuk menjawabnya. Untuk mendapatkan data penelitian yang berbentuk deskriptif kualitatif diterapkan metode observasi dengan teknik libat dan cakap, metode wawancara dengan teknik rekam dan catat, metode dokumentasi dengan teknik catat. Hasil penelitian disajikan dalam bentuk narasi. Teori yang digunakan dalam penelitian ini adalah teori semantik dengan analisis struktural.
\end{abstract}

Kata kunci: Semantik Bahasa Karo, Komunikasi, Analisis Struktur 


\section{Introduction}

This semantic research is very important to be done because semantics as a science of the meaning of words and sentences holds a large and important role in the science of language, which is in accordance with its function as a means of communication for humans. Our knowledge in semantic will help and facilitate us in selecting and using words properly and with the correct meanings. Semantic knowledge is important to be examined in order not to create misunderstanding when using a language, particularly in everyday communications, where one word often has more than one meaning.

As local (regional) and Indonesian languages are used interchangeably, Indonesian people are in general bilinguals. According Mackey and Fishman (Chaer, 2004: 84) bilingualism is defined as "... the use of two languages by speakers in their communications with others in turn".

Regional languages as a supporter of national language in accordance with the $2^{\text {nd }}$ formulation of Indonesian Language Congress in 1954 in Medan, is regarded a source of Indonesian language coaching. Some of the contributions of regional languages to the Indonesian language are, but not limited to, the field of semantics, and vocabulary. Similarly, Indonesian language influences the development of regional languages. The mutual relationship between Indonesian and regional languages is complementary in their development.

The Karo language, one of the Batak languages, is the local language used by Karonese tribe, especially those living in the Karo district of North Sumatra Province. In addtion to being used in the given district, the language is also used by fellow Karonese tribe who live in other areas. However, it is undeniable that there are often constraints of meaning (semantis) in the use of this language as a means of communication, especially when the language is used by the younger generations. So far there has never been any semantic description of Batak Karo language found. It is, therefore, necessary to conduct semantic research of Karonese language.

Based on the conditions and explanations, given above, there needs to be a system capable of synergizing between regional (local) languages as mother tongues, Indonesian language as a language of unity, and English as an international language, particularly in describing semantics to Karo Batak language.

\section{The Purpose of the Study}

The purpose of this study is to obtain a complete description of the semantics of Karo language, namely:

1. To know about the types of meaning in Karonese.

2. To know about the relation of word meaning in Karonese.

3. To know about the changing in the meanings of words in Karonese.

4. To know about the meanings of names in Karonese.

\section{Research Method}

The method used in this study is descriptive qualitative research. This means that the research is conducted as natural and objective apossible, this method underlying this research in data collection and analysis.

\section{The Semantic Theory}

Semantics can be divided into two, namely lexical semantics and grammatical semantics. The term semantics is used by linguists to refer to one branch of the science of language that operates on the level of meaning or the science of language that studies the meaning. 
Semantic types based on the level or part of the language that became the object of investigation can be divided into 4, namely (1) lexical semantics which is the semantic type whose object of research is the lexicon of a language, (2) the grammatical semantics which is the semantic type whose object of research is the grammatical meanings of the morphological level, (3) syntactic semantics which are semantic types whose goal of investigation rests on matters relating to syntax, (4) semantics of intent which is a semantics type relating to the use of figures of speech, such as metaphor .

\section{Discussion \\ Types of meaning in Karonese}

a. Lexical Meaning and Grammatical Meaning

Lexical meaning is the meaning of lexeme when the lexeme stands alone, whether it is in the basic form or derivative lexeme and its meaning is more or less fixed as can be looked up in the dictionary.

There is also a claim that the lexical meaning is the meaning of a word that has not shifted the meaning or meaning that is encountered in the dictionary or lexicon. Thus, briefly it can be said that the lexical meaning is the meaning which is in accordance with the dictionary or called the meaning which has not changed. For example:

$$
\begin{aligned}
& \text { Man } \leftrightarrow \text { eat } \\
& \text { mejin } \leftrightarrow \text { ugly } \\
& \text { Lemari } \leftrightarrow \text { wardrobe } \\
& \text { mejile } \leftrightarrow \text { beautiful } \\
& \text { medem } \leftrightarrow \text { sleep }
\end{aligned}
$$

Grammatical meaning is the meaning that arises as a result of the functioning of a lexeme in the sentence, or it can also be called as the meaning that has undergone a change from its basic meaning. a. Example: Cuping (earlobe)
Hai....i ja cuping ndu? (Hey.... where is your ears?)

lalit cuping ndu? (Don't you have ears?)

The word 'cuping' that contains the lexical meaning as one of the human's five senses which serves as tool to listen to voices (sense of hearing). If the word 'cuping' is included in one sentence, for example, "...hai, ija cupingndu?", Then the word 'cuping' (earlobe) here does not mean part of senses in the human's body (earlobe), but it means hearing, how to hear.

Apart from the examples above, the grammatical meaning can also be an affix attachment to a word or lexem which results in the transformation of lexical meaning to grammatical. For example;

makan/eat (verb) $\leftrightarrow$ makanan/food (noun) cuci/wash (verb) $\leftrightarrow$ cucian/laundry (noun)

b. Examples of words: ija matandu?, lalit matandu?. Meaning in the sentence: there is no eye? It means someone has no eyes. This kind of meaning can also be found in Karonese. For example; the word mata that means the eyes, contains the lexical meaning of the sighting sense or tool found in the body, which serves to see. If the word mata is inserted into one sentence such as "ija matandu?", here word does not mean as an organ or tool in the body, but its meaning turns more into vision or way of viewing.

c. the word babah that means mouth, contains the lexical meaning of a tool as part of the human's body that serves as a means of speaking. If the word is added in a sentence such as "La lit babahndu?", which can literally be translated into "Don't you have a mouth?" , then the word babah here does not mean as an indispensable organ or tool of the human's body, but it more precisely means voice, talk. 


\section{b. Conotative and Denotative Meanings}

\section{Denotative Meaning}

Denotative meaning is the meaning which is straightforward, plain meaning, which is objective in nature, its objectiveness is the same as conceptual meaning. What it means by objective here is that the denotative meaning can be applied generally.

Denotative meaning is the meaning which does not contain any additional meaning or feeling. The main difference between denotative meaning and connotative meaning can be seen based on whether or not the word contains an 'associated feeling'. Each word has a denotative meaning, but not all words have connotative meanings. A word is said to have a connotative meaning if the word has an 'associated feeling', whether it is positive or negative. If it does not have any associated feeling, then the word is said to be neutral. Some examples of denotative meaning in Karonese can be seen below:

1) The word ukat, which means spoon, contains denotative meaning that is an object made of bamboo or coconut shell used as a tool spooning rice or vegetables.

2) The word amak, which means mat, contains a denotative meaning that is an object made of pandanus or plastic, used as a place to sit, to dry rice, corn and bed without having to associate it to another object.

\section{Connotative Meaning}

Connotative meaning arises from the association of our feelings towards the lexeme we recite or hear. The connotative meaning usually arises as being driven by emotional feelings, whether when being happy, sad, funny, hateful and so on. Thus, the meaning of connotation in each person is generally different. Some examples of connotative meanings in Karo; the word 'rudang' (flower) in the sentence (1) 'Rudang si mejile enda kubereken man bandu tanda ateku ngena' (I give you this flower as the sign of my affection or love) will be different with the word 'rudang' (flower) as in (2) 'Ia rudang simejilena ibas kuta kami' (She is the most beautiful flower in our village). In the sentence (1) the 'rudang' (flower) contains the true meaning of a flower. While in the sentence (2) the word 'rudang' (flower) does not contain the true meaning, but here the word means a beautiful girl.

\section{c. Figurative Meaning}

In everyday life as well as in the W.J.S Poewadarminta's general Indonesian the terms of figurative meanings are used. Apparently the use of this figurative meaning is an opposition of the true meaning. Therefore, all forms of language (both words, phrases, and sentences) that do not refer to the true meaning (lexical meaning, conceptual meaning, and denotative meaning) are called to contain figurative meanings.

\section{d. Associative Meaning}

An associative meaning is a change of meaning due to the equation nature or trait. New meaning and old meaning have close ties. for example: if we eat at a food stall in Indonesia we often say or hear ' can I have another plate or a glass, Maam', but it is clear that what it means not a plate or a glass but a portion of food served in a plate or a drink served in a glass. In the Karo language this also exists, for example in a ceremony of Ngembah Belo Selambar. Based on the equation of nature, Ngembah Belo Selambar is defined as a ceremony determining the procurement of a wedding party. In this ceremony one of the shows is the handingover of kampil or a traditional pouch with betel leaves in it. 
e. Idiomatic Meaning and Sayings

Idiomatic Meaning is a word that has a special meaning and cannot be translated denotatively into other languages and situations. Idiomatics have a fixed nature and are used to express some intentions with figurative meanings. For example; Adi pang ridi, ula mbiar basah, which literally means 'If you dare to take a shower, do not be afraid of getting wet', which actually means if one dares to do something, he/she must dare to bear the risk to give responsibility.

A proverb is a group of words or sentences that usually define a certain meaning of comparison, contradiction, satire, and affirmation. The order of sentences in the proverb is fixed. For example in Karonese; bagi biang ras kucing, which literally means 'like dogs and cats', where it actually points out to people who are always fighting and are never able to unite.

\section{Meaning Relation}

In every language, including Karonese language, we often encounter a relationship of meaning or semantic relation between a word or other language unit with other words or units of language. This relationship or relation of meaning may be related to the similarity of meaning (synonym), opposite meaning (antonym), meaning association (hyponimi), different meaning (homonymy), and so on.

a. synonym; is another name for the same object. Sinonym also means words that are similar or almost similar in meaning. Some examples in Karonese can be seen as follows;

rudang $\leftrightarrow$ flower

mejile $\leftrightarrow$ beautiful

ndigan $\leftrightarrow$ when b. antonym; a statement in the form of words, in the form of phrases or sentences which are considered to be the opposite of the meanings of the other expressions. Here are some examples in Karonese;

galang (big) $\leftrightarrow$ kitik (small) '

gedang (long) $\leftrightarrow$ gendek (short)

mejin (ugly) $\leftrightarrow$ mejile (beautiful)

c. homonym; a statement of word, phrase, or sentence that has the same pronunciation or origin as another, but its meaning is not the same. In Karonese some examples can be seen below;

kuah which means (1) broth/vegetable soup, (2) pitty/mercy,

man which means (1) eating, (2) to someone as a receiver.

\section{Changes in the Meaning of Words}

In the growth and development of language, the meaning of a word can change. The changes can be seen from various types. Some of the most significant among the various types of events that change meaning are the expanded meaning, narrow, ameliorative, pejorative, total change, euphemism, dysphmism, association, and synesthesia.

\section{Expanded}

The change in the expanded meaning is a phenomenon that occurs in a word or lexem that originally had only a meaning, but then because of various factors became having other meanings. For example, the word saudara siblings which originally meant from the same belly has now expanded in its meaning to anyone who has blood relation. Even all people who have an equal are called saudara or brothers. Likewise, the word putera-puteri which were used to be only used for the king's sons and daugthers, 
can now be used to call sons and daughters. Below are some examples in Karonese:

The word sumbuyak ' from the same belly', used to mean a person who shares the same father and mother with us, now that word can mean all those who are from the same clan as us. The word impal, formerly referred only to the child of our uncle, now the word may be used to all people who has different family clan names.

\section{Narrowing}

What is meant by the change in narrowed meanings is a phenomenon that occurs in a word that originally has quite a broad meaning, which then changed to a limited meaning only. Or in other words, it can be said that the scope of meaning in the past was wider than the present meaning. The word sarjana or scholar used to be used to call all intellectuals or clever people, now it only means people who have graduated from a college (university). Thus, a person who is not a college graduate can not be called a scholar no matter how intteligent the person is. Conversely, no matter how low a person's achievement so long as he/she has graduated from a university is called a scholar. Here is an example in Karonese;

The word uis or cloth means a traditional piece of fabric consists of of uis gara 'red cloth', uis nipes 'custom fabric', uis mbentar 'white cloth'.

\section{Ameliorative and Pejorative}

What is meant by ameliorative change of meaning is a process of change of meaning which at first has a lower meaning than it is now. Or in other words the new meaning is considered higher or better than the former meaning. While pejorative is a change of meaning that resulted in a word or phrase described has worse, unpleasant and lower in quality compared to the original (former) meaning. In pejorative, the new meaning is felt lower in value than the old meaning. Here is an example in Karo;

Ameliorative Pejorative
Neaning
Perbulangen dilakina
wife

\section{Synestesia}

The word synesthesia comes from the Greek sun which means 'similar' and aisthetikas meaning 'look'. The change of meaning due to the tendency to change the response with the aim of asserting the intention is called synesthesia. Or in other words synestesia is the exchange of responses between the sense and the other sense. An example in Karonese can be seen below;

The word meser 'spicy' is associated with the taste buds or tongue, but if we say / meser kal pengeranana / 'his/her words are so spicy' then it is related to the hearing sense or ear.

\section{Conclusion and Suggestion Conclusion}

1) Semantic research needs to be done in Karonese because the word meaning is very important and useful as a communication tool. Semantic knowledge will facilitate us in choosing and using words with the right and correct meaning. Knowledge of Karonese semantics, can also facilitate communications to be delivered by the speaker to the listener.

2) In the semantics of Karonese language there are various meanings, namely:

3) lexical meanings and grammatical meanings

4) denotative meaning and connotative meaning

5) affective meaning

6) figurative meaning

7) associative meaning

8) idiomatic meanings and proverbs. 
9) The relations of meaning found in Karonese are synonym, antonym, homonym, polysemic, and hyponym.

10) Changes in the meaning of words that occur in the Karonese are the expansion of meaning, narrowing of meaning, ameliorative, pejorative and synesthesia.

11) The reasons for the changes of meaning in Karonese are the change of meaning due to the change of environment, the change of meaning is also caused by the combination of words and the difference of responses.

\section{Suggestion}

1) Semantic research into Karonese and other regional languages need to be done in order to know the development of the meaning of words and changes in the meaning of words in the use of language. Because without the existence of semantic knowledge it will be difficult for us to choose the words with the right and correct meaning.

2) Research into Karonese language needs to be conducted for the sake of preservation and development of the given regional language.

3) Guidance and training on the local language of Karonese as a supporter of national language and culute is important to do.

\section{References:}

Amnuddin. 1988. Semantik, Pengantar Studi Tentang Makna. Sinar Baru. Bandung.

Chaer Abdul. 1994. Pengantar Semantik Bahasa Indonesia. Bandung. Pustaka Prima.

Dj Sudarma Fatimah. 1993. Semantik 2 Pemakaian Ilmu Makna. Pt. Eresko Bandung.

Leech G. 2003. Semantik. Pustaka Pelajat Yogyakarta.

Lembaga Bahasa Nasional. 1995. Laporan Penelitian Language. Loyaly :
Sebuah Study Kasus Kesetiaan Berbahasa Etnis Oleh Masyarakat Toba Di Kotamadya Medan. Medan : Lembaga Penelitian USU.

Nasution. S. 1992. Metode Penelitian Naturalistik-Kualitatif. Bandung : Tarsito.

Palmer, F.P. 1981. Semantics. Cambridge : Cambridge University Press.

Sibarani, Robert Prof. Dr., M.S. 2004. Semantik Bahasa Toba. USU.

Seuren, Peter. A.M, 1985. Discourse Semantics. Oxford. : Bablocwell.

Sudaryanto. 1985. Metode dan aneka teknik analisis bahasa : Gajahmada Universty Press. 